\title{
Regional variations of carbonates in postglacial sediments and response of physical sediment properties to climatic events and vegetation
}

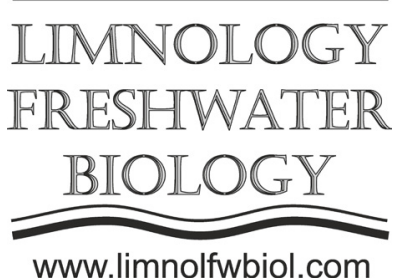

\author{
Gedminienè L. ${ }^{1 *}$, Druzhinina O. ${ }^{2}$, Stančikaitè M. ${ }^{1}$ \\ ${ }^{1}$ Nature Research Centre, Akademijos Str. 2, LT-08412, Vilnius, Lithuania \\ ${ }^{2}$ Shirshov Institute of Oceanology, Russian Academy of Science, 36, Nahimovskiyprospekt, Moscow, Russia, 117997/Herzen University, \\ 48, Nab. Mojki, Saint-Petersburg, Russia, 191186
}

\begin{abstract}
Despite an increasing number of geochemical and palynological data representing the Lateglacial and Holocene sediment sequences that are used to evaluate long-term and short-term interactions between soil and vegetation, the main environmental drivers of these processes are not fully understood so far. Soil composition, vegetation and lake evolution are diverse in all sites analysed in this study. The work was aimed to provide a comparison of the evolution of conifer and broad-leafed plant taxa spread with sediment geochemical data, including organic carbon and $\mathrm{CaCO}_{3}$ changes during the same sedimentation period. Problems addressed here analyze the increased carbonate mobility initiated by the invasion of conifers and a subsequent drop in soil $\mathrm{pH}$. Together with this, the influence of organic material on accumulation of carbonates and sensitivity of Mn and Fe to redox conditions was evaluated. In general, chronologically defined changes in sediment composition revealed the intervals of more stable environmental conditions during which biotic factors were of greater importance in altering vegetation structure and the periods during which scarce vegetation had a negative impact on soil development leading to its progressive deterioration. Related changes occurred in sediments from different lakes; however, due to geographical position, responses to warming or cold events were a bit asynchronous.
\end{abstract}

Keywords: lake sediments, organic matter, carbonates, conifers, postglacial palaeoenvironmental changes, redox conditions.

\section{Material and methods}

The following contrasting regions representing various watersheds - three sites in Lithuania (Lieporiai, Čepkeliai, and Dūkšteliai) and one site in Kaliningrad Region, Russia (Kamyshovoe) (Fig. 1) - were investigated with the intension of providing information on terrestrial and aquatic environment variations during the postglacial. Standard methods described in Stančikaitè et al. (2019), Edwardsson et al. (2018), Gedminienè et al. (2019), were applied for pollen, LOI, geochemical analyses, and ${ }^{14} \mathrm{C}$ dating. Radiocarbon measurements were focused on bulk sediments. The chronology of sequences was based on age-depth models constructed applying the P_Sequence function in the OxCal 4.3.2 software. However, biostratigraphical information also supported the chronological model in Gedminiene et al. (2019) indicating the main stages of vegetation history in the lake catchment. A mean value of the modeled age was used for the calculation of the sedimentation rate. Various statistical and mathematical methods indicated in Gedminienè and Uogintas (2017) and publications mentioned above were employed to evaluate interrelations between proxies. Significance levels for element correlation were calculated applying StatSoft Statistica 8 MR-3sofware.

\section{Results and discussion}

In the present study, the $\mathrm{LOI}_{550}$ and sedimentation rate allowed us to identify the increasing importance of bioproductivity. One of the highest values of the accumulation rate was noted (Fig. 2) over a time span covering an interval between 13500 and $12500 \mathrm{cal} \mathrm{yr}$ $\mathrm{BP}$, which is coincident with GI-1a, the so-called Alleröd Thermal Maximum. Together with this, the Mn/Fe ratio markedly increased, and a high percentage of $\mathrm{LOI}_{950}$ and a highly variable but still low concentration of $\mathrm{LOI}_{550}$ were observed in all the sequences investigated. However, carbonate content varied remarkably throughout this time interval: Lieporiai sediment was composed of purely white and soft calcareous gyttja 


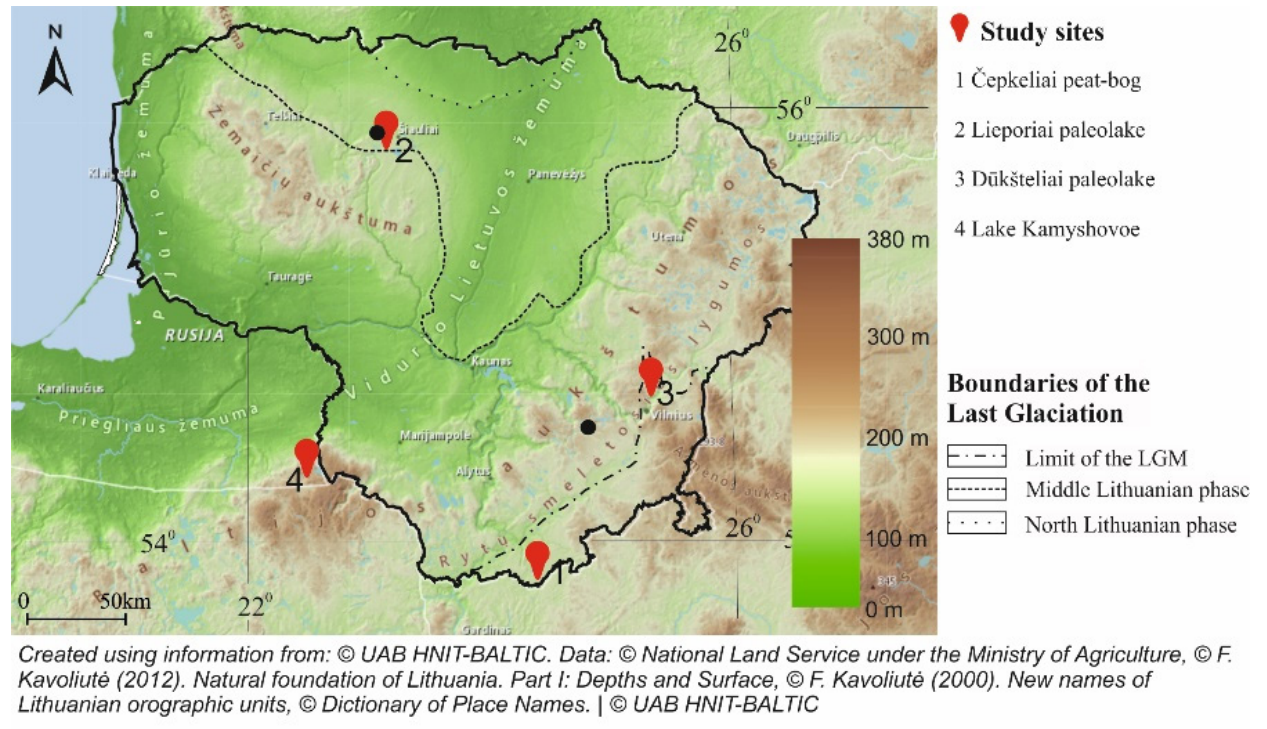

Fig.1. Location of study sites.

$\left(\mathrm{LOI}_{950} 38 \%\right.$ ), while Čepkeliai and Dūkšteliai were also calcareous, but sediments were silty and enriched with clay $\left(\mathrm{LOI}_{950} 30 \%\right.$ and $20 \%$, respectively). The lowest concentration of carbonate was recorded in the Kamyshovoe sequence. Whilst geochemical elements determine allogenic input, pollen carries a more regional signal, which documents the flourishing of the Pinus-predominated forest in the region. The presence of Pinus and the enhanced mobility of carbonates had previously been investigated by Engstrom and Hansen (1985) and Apolinarska et al. (2012).

A sudden rise in siliciclastic input coincided with the opening of vegetation, i.e. spread of herbs and grasses was noted at about $12600 \mathrm{cal}$ yr BP in the sequences analyzed. This reversal in the environmental pattern may indicate an intensification of soil erosion processes under more open lakeshores. The interval described might correlate with the GS-1 cooling event.

With the onset of the Holocene, successional changes started in surrounding vegetation (i.e. gradual closing of vegetation and increasing representation of broad-leafed taxa) and in soil composition of the sites investigated. However, the evolution of the investigated sedimentation basins differed remarkably according to information obtained. For example, $\mathrm{LOI}_{550}$ data confirm that overgrowing processes in Čepkeliai started earlier than in other sites. In Čepkeliai, a rise in organic sedimentation started at about $9500 \mathrm{cal} \mathrm{yr} \mathrm{BP,}$ and the coring site finally overgrew at about $6000 \mathrm{cal}$ yr BP according to our data. Meantime, Lake Dūkšteliai transformed into a wetland at about $3500 \mathrm{cal} \mathrm{yr} \mathrm{BP,}$ though the representation of organic matter increased from about 8000 cal yr BP onward. Decreasing participation of siliciclastic sedimentation started after 9000 cal yr BP in Kamyshovoe. In conjunction, sediments started to consist of a higher concentration of organic matter at that time. Such reversal may indicate that at the beginning deep lake shores got stabilized by overgrowing vegetation, but highly soluble $\mathrm{Ca}$ was easily washed from surrounding soils and due to a high biogenic removal of $\mathrm{CO}_{2}$ and accompanying increase in $\mathrm{pH}$ the production of $\mathrm{CaCO}_{3}$ could also be increased. This effect was widely studied by Walter E. Dean (1999).

Our data shows two trends of carbonate sedimentation. The first of the trends observed is well seen during the Lateglacial period in all lakes, excluding Kamyshovoe. At that time, increased concentrations of $\mathrm{LOI}_{950}$ and high concentrations of $\mathrm{Ca}$ and $\mathrm{Ca} / \mathrm{Ti}$ were noticed. Simultaneously, Pinus played a major role in surrounding vegetation. However, the content of organic matter in the sediments of lakes was very low. Another type of carbonate sedimentation can be seen during the Holocene. At that time, we observed high concentrations of $\mathrm{LOI}_{550}$ which had a correlating trend only with $\mathrm{Ca}$ /Ti high values, while $\mathrm{Ca}$ and $\mathrm{LOI}_{950}$ values decreased. This means that sediment saturation with the organic matter had an impact on lithogenic elements (i.e. Ti), but enrichment with Ca remained the same. This reversal is directly connected with the trophic stage of lakes, as we see equal trends in different lakes but at different stages of lake development. Together with this, during the Early and Middle Holocene we can see a decreasing Pinus curve, which again increased from about $6000 \mathrm{cal}$ yr BP in Čepkeliai and $4000 \mathrm{cal}$ yr BP in Dūkšteliai. From about $8000 \mathrm{cal} \mathrm{yr} \mathrm{BP,} \mathrm{a}$ gradual Picea spreading started. However, conifer and $\mathrm{Ca} / \mathrm{Ti}$ correlation coefficients, which represent this sedimentation period, were a bit lower in comparison with $\mathrm{Ca} / \mathrm{Ti}$ and $\mathrm{LOI}_{550}$ correlation coefficients.

\section{Conclusions}

During the Lateglacial period, bioproduction onshore was poor; therefore, conifer vegetation could have a direct effect on soil erosion and carbonate migration to lake basins. In the Holocene, the vegetation became intense, and conifer impact on carbonate migration lowered. However, Picea migration to the region during the Holocene from about $6000 \mathrm{cal} \mathrm{yr}$ BP could have become the main reason for higher carbonate concentrations in lake sediments, as the 


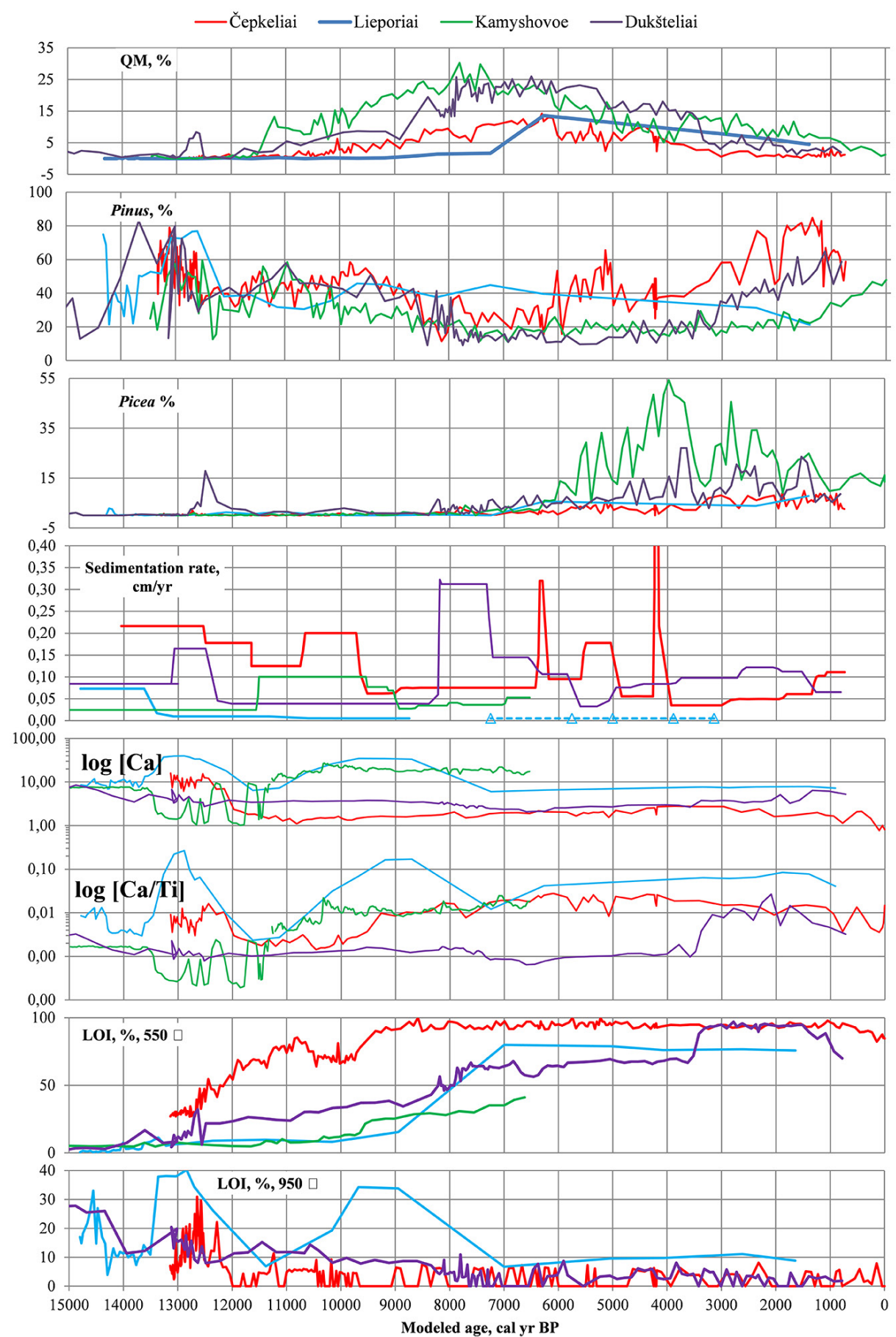

Fig.2. Preliminary results of selected data. QM - Quercetum mixtum (thermophilous pollen); Pinus - pine; Picea - spruce; LOI ${ }_{550}$ - loss-on-ignition when heating at $550^{\circ}$ temperature; $\mathrm{LOI}_{950}$ - loss-on-ignition when heating at $950^{\circ}$ temperature.

content of $\mathrm{Ca} / \mathrm{Ti}$ increased simultaneously. Together with this, some carbonates could also be incorporated in sediments due to a high biogenic removal of $\mathrm{CO}_{2}$.

\section{Acknowledgments}

Special thanks are addressed to the Nature Research Centre for a possibility to use the facilities of the Open Access Centre. Part of the investigations was financed by the Research Council of Lithuania Grant, No. S-MIP-17-133, and Russian Foundation for Basic Research, No. 09-06-00150/12-05-33013.

\section{References}

Apolinarska K., Woszczyk M., Obremska M. 2012. Late Weichselian and Holocene palaeoenvironmental changes in northern Poland based on the Lake Skrzynka record. Boreas 41(2): 292-307.

Dean W. E. 1999. The carbon cycle and biogeochemical dynamics in lake sediments. Journal of paleolimnology 21(4): 375-393.

Edvardsson J., Stančikaitė M., Miras Y. et al. 2018. Late-Holocene vegetation dynamics in response to a changing climate and anthropogenic influences-Insights from stratigraphic records and subfossil trees from southeast Lithuania. Quaternary Science Reviews 185: 91-101. 
Engstrom D. R., Hansen, B. C. S. 1985. Postglacial vegetational change and soil development in southeastern Labrador as inferred from pollen and chemical stratigraphy. Canadian Journal of Botany 63(3): 543-561.

Gedminienè L., Šiliauskas L., Skuratovič Ž. et al. 2019. The Lateglacial-Early Holocene dynamics of the sedimentation environment based on the multi-proxy abiotic study of Lieporiai palaeolake, Northern Lithuania. Baltica 32 (1): 91-106.

Gedminienė L., Uogintas D. 2017. Environmental drivers of Lateglacial and Holocene lake development: an example of Lieporiai lake, north Lithuania. In: annual conference of $\mathrm{PhD}$ geology students. Geologija. Geografija: 166-169.

Stančikaitė, M., Gedminienè, L., Edvardsson, J. et al. 2019. Holocene vegetation and hydroclimatic dynamics in SE Lithuania-Implications from a multi-proxy study of the Čepkeliai bog. Quaternary International 501(A): 219-239. 